REVIEW

\title{
Rett syndrome: clinical review and genetic update
}

\author{
LS Weaving, C J Ellaway, J Gécz, J Christodoulou
}

J Med Genet 2005;42:1-7. doi: 10.1136/jmg.2004.027730

Rett syndrome (RS) is a severe neurodevelopmental disorder that contributes significantly to severe intellectual disability in females worldwide. It is caused by mutations in MECP2 in the majority of cases, but a proportion of atypical cases may result from mutations in CDKL5, particularly the early onset seizure variant. The relationship between MECP2 and CDKL5, and whether they cause RS through the same or different mechanisms is unknown, but is worthy of investigation. Mutations in MECP2 appear to give a growth disadvantage to both neuronal and lymphoblast cells, often resulting in skewing of $X$ inactivation that may contribute to the large degree of phenotypic variation. MeCP2 was originally thought to be a global transcriptional repressor, but recent evidence suggests that it may have a role in regulating neuronal activity dependent expression of specific genes such as Hairy2a in Xenopus and Bdnf in mouse and rat.

See end of article for authors' affiliations

Correspondence to: Professor J Christodoulou, Western Sydney Genetics Program, The Children's Hospital at Westmead, Locked Bag 4001 Westmead, 2145, NSW, Australia; johnc@ chw.edu.au

Received 1 October 2004 Revised 1 October 2004 Accepted 5 October 2004
$\mathrm{R}$ ett syndrome (RS) was first described as a clinical entity in the German literature in 1966. ${ }^{1}$ Hagberg and colleagues increased awareness of the disorder in the English medical literature in 1983 with a further description of the condition in 35 girls with strikingly similar clinical features of "progressive autism, loss of purposeful hand movements, ataxia, and acquired microcephaly". ${ }^{2}$ RS is now recognised as a panethnic disorder, and presents an ever widening clinical phenotype. ${ }^{3}$ The estimated cumulative incidence of RS in Australia is 10 per 100000 females by the age of 12 years $^{4}$ and it is considered to be the second most common cause, after Down's syndrome, of severe mental retardation in females. ${ }^{5} \mathrm{RS}$ is a severe neurodevelopmental disorder characterised by the progressive loss of intellectual functioning, fine and gross motor skills and communicative abilities, deceleration of head growth, and the development of stereotypic hand movements, occurring after a period of normal development. Girls with RS often develop seizures, a disturbed breathing pattern with hyperventilation and periodic apnoea, scoliosis, growth retardation, and gait apraxia. ${ }^{2}$

The association of RS with mutations in the methyl-CpG binding protein 2 gene (MECP2) was recognised in 1999. ${ }^{6}$ The MeCP2 protein is known to bind methylated $\mathrm{CpG}$ sequences and recruit silencing complexes that lead to compaction and silencing of surrounding chromatin. The mechanism(s) by which MeCP2 dysfunction causes RS remains somewhat of an enigma, but recent advances in our knowledge of its precise roles in neuronal and other cell types have gone a long way towards clarifying this issue. Nevertheless, diagnosis of RS remains a clinical one, as a small proportion of clinically well defined RS patients $(\sim 5-10 \%)$ do not appear to have MECP2 mutations.

\section{CLINICAL OVERVIEW}

RS is characterised by a specific developmental profile, with the diagnosis of RS being based on a consistent constellation of clinical features and the use of established diagnostic criteria. ${ }^{7}$ More recently, refined diagnostic criteria have been proposed to clarify previous ambiguities in interpretation of clinical features ${ }^{8}$ (table 1, fig 1), and guidelines have been developed to aid researchers in being more consistent in their reporting of clinical features in RS patients. ${ }^{9}$

The diagnostic criteria for classical RS include a normal prenatal and perinatal period with normal developmental progress for the first 5-6 months of life. The birth head circumference is normal with subsequent deceleration of head growth, usually leading to microcephaly. Between 3 months and 3 years there is reduction or loss of acquired skills such as purposeful hand function, vocalisation, and communication skills. The hallmark of RS is the intense, sometimes continuous, stereotypic hand movements, which develop after the loss of purposeful hand movements. Patterns consist of tortuous hand wringing, hand washing, clapping, patting, or other more bizarre hand automatisms, during waking hours. ${ }^{5}$ A jerky truncal and or gait ataxia is another prominent feature. Supportive diagnostic criteria include breathing dysfunction, EEG abnormalities, spasticity, peripheral vasomotor disturbance, scoliosis, and growth retardation. It has been suggested that the classical RS phenotype can be described as having a four stage clinical evolution, and this has helped in discussing the natural history of the disorder with parents. ${ }^{10}$ According to the recently revised criteria, ${ }^{8}$ the clinical diagnosis of RS is excluded if there is evidence of a storage disorder, retinopathy, cataract, or optic atrophy, an identifiable metabolic or neurodegenerative disorder, an acquired neurological disorder, or evidence of perinatal or postnatal brain injury. It must not be

Abbreviations: $B D N F$, brain derived neurotrophic factor; CDKL5, cyclin dependent kinase-like 5; ISSX, infantile spasms syndrome, $\mathrm{X}$ linked; MECP2, methyl-CpG binding protein 2; $M R$, mental retardation; ORF, open reading frame; RS, Rett syndrome; STK9, serine threonine kinase 9; XLRS, X linked retinoschisis 
Table 1 Revised diagnostic criteria for classical and variant RS. Derived from tables 3 and 4 in the paper by Hagberg et al. ${ }^{8}$

\begin{tabular}{|c|c|c|c|}
\hline & Necessary criteria & Supportive criteria & Exclusion criteria \\
\hline Classical RS & $\begin{array}{l}\text { Apparently normal prenatal and } \\
\text { perinatal history } \\
\text { Psychomotor development normal } \\
\text { during the first } 6 \text { months (may be } \\
\text { delayed from birth) } \\
\text { Normal head circumference at birth } \\
\text { Postnatal deceleration of head } \\
\text { growth (most individuals) } \\
\text { Loss of purposeful hand skills } \\
\text { between } 0.5-2.5 \text { years } \\
\text { Stereotypic hand movements } \\
\text { Evolving social withdrawal, } \\
\text { communication dysfunction, loss of } \\
\text { acquired speech, cognitive impairment } \\
\text { Impaired or deteriorating locomotion }\end{array}$ & $\begin{array}{l}\text { Breathing disturbances while awake } \\
\text { Bruxism } \\
\text { Impaired sleeping pattern from early } \\
\text { infancy } \\
\text { Abnormal muscle tone accompanied } \\
\text { by muscle wasting and dystonia } \\
\text { Abnormal muscle tone accompanied } \\
\text { by muscle wasting and dystonia } \\
\text { Peripheral vasomotor disturbances } \\
\text { Progressive scoliosis or kyphosis } \\
\text { Growth retardation } \\
\text { Hypotrophic small and cold feet } \\
\text { and/or hands }\end{array}$ & $\begin{array}{l}\text { Organomegaly or other evidence of a } \\
\text { storage disorder } \\
\text { Retinopathy, cataract, or optic atrophy } \\
\text { History of perinatal or postnatal } \\
\text { brain damage } \\
\text { Identifiable inborn error of metabolism } \\
\text { or neurodegenerative disorder } \\
\text { Acquired neurological disorder due to } \\
\text { severe infection or head trauma }\end{array}$ \\
\hline Variant RS & $\begin{array}{l}\text { At least } 3 \text { of the } 6 \text { main criteria } \\
\text { At least } 5 \text { of the } 11 \text { supportive criteria } \\
\text { Main criteria } \\
\text { Absence or reduction of hand skills } \\
\text { Reduction or loss of speech } \\
\text { (including babble) } \\
\text { Hand stereotypies } \\
\text { Reduction or loss of } \\
\text { communication skills } \\
\text { Deceleration of head growth } \\
\text { from early childhood } \\
\text { Regression followed by recovery } \\
\text { of interaction }\end{array}$ & $\begin{array}{l}\text { Breathing irregularities } \\
\text { Air swallowing or abdominal bloating } \\
\text { Bruxism } \\
\text { Abnormal locomotion } \\
\text { Scoliosis or kyphosis } \\
\text { Lower limb amyotrophy } \\
\text { Cold, discoloured feet, usually } \\
\text { hypotrophic } \\
\text { Sleep disturbances, including night } \\
\text { time screaming } \\
\text { Inexplicable episodes of laughing or } \\
\text { screaming } \\
\text { Apparently diminished pain sensitivity } \\
\text { Intense eye contact and/or eye pointing }\end{array}$ & \\
\hline
\end{tabular}

forgotten that RS may occur coincidently with other disorders, ${ }^{11}{ }^{12}$ potentially delaying the diagnosis.

With increasing experience it has become clear that females with RS may present with a much broader phenotype than originally described. A number of variants have been described, which may be more or less severe than the clinical picture seen in classical RS. ${ }^{13}$ Although initially thought to be a disorder exclusively affecting females, males with a Rettlike phenotype have been reported occasionally, including those who also have a 47XXY karyotype, ${ }^{14}$ males who are mosaic for severe mutations, ${ }^{15}$ and males who may have milder mutations. ${ }^{16}$ In addition, other non-RS phenotypes have been associated with MECP2 mutations (see below).

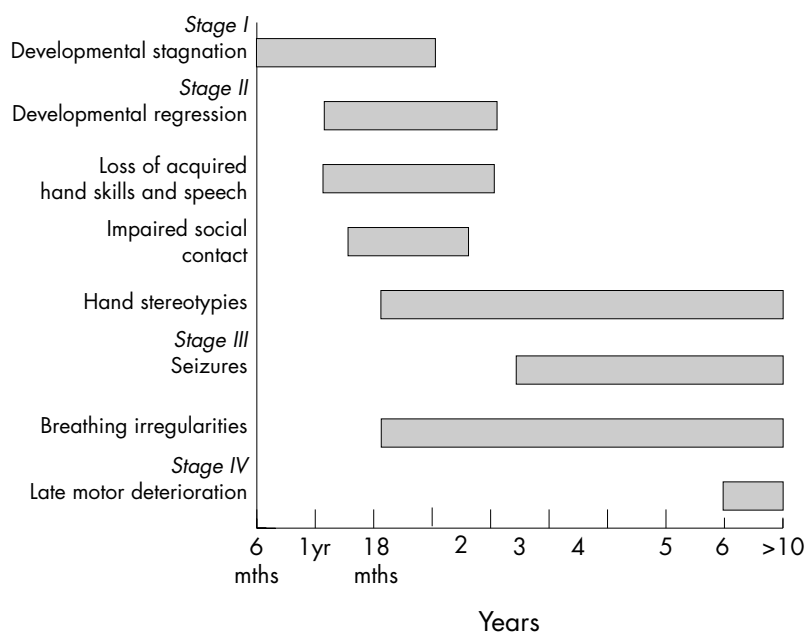

Figure 1 Staging system for classical Rett syndrome. Derived from Hagberg and Witt-Engerstrom. ${ }^{10}$

\section{Management}

Medical management of RS is essentially symptomatic and supportive. A multidisciplinary team approach is advocated, aimed at maximising each patient's abilities and facilitating any skills that may be emerging. Management should include psychosocial support for the families, development of an appropriate education plan, and assessment of available community resources. Parent support groups are crucial in providing support for families. Pharmacological treatments for RS have included L-carnitine, which may lead to an improvement in patient wellbeing and quality of life, ${ }^{17-19}$ magnesium to reduce the episodes of hyperventilation, ${ }^{20}$ and melatonin to improve sleep dysfunction. ${ }^{21}$ Evaluation of the efficacy of these and other potential treatments on the horizon will require carefully constructed clinical trials, using validated instruments for measuring clinical improvements and relevant biochemical markers.

Decreasing repetitive purposeless hand movements can be achieved by the use of various arm restraints, such as soft elbow splints, and are occasionally helpful in training specific hand skills such as self feeding. These methods are also helpful in decreasing agitation and self injurious behaviour. ${ }^{22}$

Feeding problems are common in RS. ${ }^{23}$ Several factors contribute to this, including poor caloric intake secondary to swallowing difficulties and immature chewing patterns, and energy expenditure imbalances with calories used to sustain motor activities at the expense of growth. Despite a voracious appetite, some girls experience poor weight gain. This may be because the majority of girls are unable to feed themselves, and very few develop mature chewing patterns. A gastrostomy tube may be used as an alternate route to supplement nutrition. Gastro-oesophageal reflux may respond to conservative medical treatment with anti-reflux agents, thickened feeds, and positioning. Budden found that frequent small feeds during the day with added carbohydrate foods not only maintained growth and weight gain, but had a 
definite influence on agitation and irritability in younger girls. $^{23}$

The majority of RS girls lose verbal expressive language, although some retain some speech or single word expressions. Alternative forms of communication that may be used include communication boards, technical devices, and switch activated systems. These are used for making choices and facilitate environmental access. Some girls are also able to communicate through eye pointing, gestures, body language, and hand pointing. ${ }^{22}$ These abilities need to be recognised and encouraged.

Seizure control is a common problem in the care of females with RS. A major challenge in diagnosis may be differentiating seizures from the behavioural patterns often associated with RS. Breathing irregularities such as breath holding and hyperventilation, episodes of motor activity such as twitching, jerking, or trembling, or a cardiac arrhythmia associated with a prolonged QT interval are most commonly confused with seizures. Studies using prolonged video EEG polygraphic monitoring indicate that the occurrence of seizures is overestimated. Most episodes identified by parents represent non-epileptic behavioural events. On the other hand, some actual seizures may be unrecognised by parents or occur during sleep. ${ }^{24}$ EEG telemetry and parental education may assist in identifying true seizure events.

Prolonged heart rate corrected QT values have been reported in association with RS. ${ }^{25}{ }^{26}$ Prokinetic agents (such as cisapride), antipsychotics (such as thioridazine), tricyclic antidepressants (such as imipramine), anti-arrhythmics (such as quinidine, sotolol, amiodarione), anaesthetic agents (such as thiopental, succinylcholine), and antibiotics (such as erythromycin, ketoconazole) should therefore be avoided because of the possibility of precipitating electrocardiogram QT abnormalities and cardiac arrhythmias.

Scoliosis is found in approximately $65 \%$ of girls with RS. Some girls require bracing, while others require surgical intervention. ${ }^{22}{ }^{27}$ Increased tone in the Achilles tendon is one of the earliest manifestations of onset of rigidity, usually followed by toe walking. It is important to maintain ambulation, and so bilateral ankle foot orthoses need to be used to prevent foot deformities, maintain foot alignment, and keep the heel cords lengthened. Physiotherapy is also required to keep the Achilles tendons stretched. ${ }^{22}$

\section{MECP2 MUTATIONS IN RS AND OTHER CLINICAL PHENOTYPES}

The MECP2 gene is located at q28 on the human $\mathrm{X}$ chromosome, and has been demonstrated to undergo $X$ inactivation in mice and humans. ${ }^{28}{ }^{29}$ It encodes a protein of 498 (MeCP2B or MeCP2 $\alpha$; encompassing exon 1 but not exon 2 ) or 486 amino acids (MeCP2A or MeCP2 $\beta$; encompassing part of exon 2 but not exon 1), depending on the use of alternative splice variants, ${ }^{30} 31$ (figure 2A), with MeCP2B being the predominant isoform in brain. MeCP2A may predominate in other tissues, such as fibroblast and lymphoblast cells. ${ }^{31}$ There are known MeCP2 orthologues in rat, mouse, monkey, Xenopus, and zebrafish (http://mecp2. chw.edu.au/mecp2/info/MECP2_homologues.shtml), suggesting that MeCP2 has served important functions throughout vertebrate evolution, although these may be different between widely divergent species.

Apart from a nuclear localisation signal, MeCP2 has three functional domains (figure 2B). The methyl-CpG binding domain, at position $0-174$, binds exclusively to symmetrically methylated CpGs. The transcriptional repression domain, at position 219-322, is able to recruit co-repressor complexes that mediate repression through deacetylation of core histones, with consequent compaction of DNA into heterochromatin. ${ }^{32}{ }^{33} \mathrm{MeCP} 2$ interacts with either the Sin3A/HDACI
A
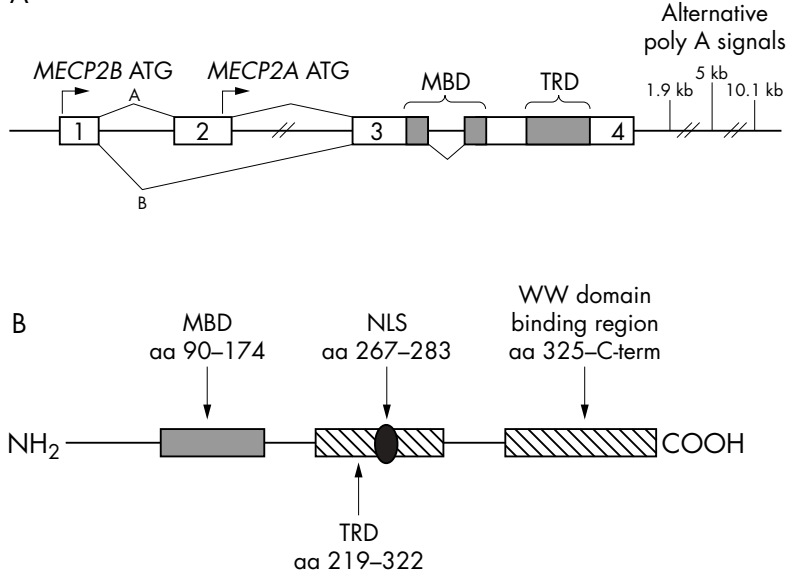

Figure 2 (A) Structure of the MECP2 gene and mRNA (adapted from Kriaucionis and Bird, ${ }^{30}$ and Mnatzakanian et $a^{\beta 1}$ ). Alternative splicing for the $A(\beta)$ isoform is shown above the gene and for the $B(\alpha)$ isoform below the gene. The $B$ isoform has the highest expression in brain, and mutations specific to this isoform are sufficient to cause RS. ${ }^{31}$ (B) Structure of the $B$ isoform MeCP2 protein sequence. The protein is 486 amino acids in size. MBD, methyl-CpG binding domain; TRD, transcription repression domain; NLS, nuclear localisation signal.

or Ski/NcoR/HDACII repression complexes to do this. ${ }^{34}$ In addition, MeCP2 also has HDAC independent silencing capabilities. ${ }^{35}$ The WW domain binding region, from residue 337 to the C terminus, specifically binds to group II WW domains of splicing factors including formin binding protein II and Huntington yeast protein C (HYPC). ${ }^{36}$ MeCP2 thus has the capability to interpret methylated CpGs differently, possibly leading to different downstream responses, depending on the context.

Following the first report of $M E C P 2$ mutations in RS patients, ${ }^{6}$ there was intense mutation screening of cohorts of patients, and attempts to draw phenotype-genotype correlations, with conflicting results. ${ }^{37-43}$ Several mutation databases have also been developed (http://homepages.ed.ac.uk/ skirmis/; http://mecp2.chw.edu.au/). ${ }^{44}$ There is some agreement that missense mutations are generally milder than nonsense mutations, that mutations in the methyl binding domain are often more severe than those in the transcription repression domain, and that skewing of $\mathrm{X}$ inactivation can modulate the severity of the disorder. In addition, studies of a number of patients with the same mutation have made it possible to draw firm conclusions as to the severity of specific mutations..$^{43} 46$ However, variation may still be seen between patients with the same mutation and apparently random $X$ inactivation, suggesting that other mechanisms may also modulate the clinical severity, with differences in upstream regulators or downstream targets of $\mathrm{MeCP} 2$ being possible candidates.

The association of skewing of $\mathrm{X}$ inactivation with RS has long been a subject of debate. An increased incidence of skewing has been reported by some authors, ${ }^{41}{ }^{47-49}$ but not others. ${ }^{50-54}$ Skewing has been investigated in a limited number of regions in a small number of RS brain samples, ${ }^{55}$ and these authors found random inactivation in 10/10 samples that were informative for the assay. However, it has been demonstrated that both lymphocytes ${ }^{56}$ and neuronal cells $^{57}$ expressing mutant $\mathrm{MeCP} 2$ are at an in vitro growth disadvantage. In addition, two different MeCP2 null mouse models showed uniform distribution of MeCP2 in the brains of heterozygous females, but skewed $X$ inactivation favouring the wild type allele. ${ }^{58-60}$ Young and Zoghbi ${ }^{57}$ also identified 
regional skewing in the brains of mice carrying the common 308X mutation, and we have demonstrated that there may be regional variation in human RS brains. ${ }^{61}$ Furthermore, it has been demonstrated that skewing in the brains of mutant mice correlates with the phenotypic outcome, with the chance of manifestation of certain symptoms decreasing with increasing expression of the wild type allele. ${ }^{57}$ These studies, combined with previous studies of $X$ inactivation in RS patients, strongly suggest that skewing plays a significant role in modulating phenotypic severity.

Prior to the identification of the MeCP2B (MeCP2 $\alpha$ ) isoform, mutation detection efforts had focused on PCR based approaches to screening exons 2, 3, and 4. More recently, it has been recognised that up to $15 \%$ of apparently MECP2 mutation negative individuals have large deletions (spanning kilobases) that would be missed by this approach. $^{62-65}$ In addition, the identification of the new MeCP2 isoform has raised the speculation that some individuals may have mutations in exon $1,{ }^{31}$ although in our experience this appears to be an uncommon event (unpublished observations). ${ }^{66}$ Using a combination of PCR based screening approaches for the MECP2 coding regions and one or other method to screen for large deletions, it has been suggested that pathogenic MECP2 defects will be identified in up to $90-95 \%$ of $\mathrm{RS}$ cases. $^{63}$ A remaining challenge is to identify the genetic defect in the remaining $5-10 \%$ of cases, with possible regions of interest including the $M E C P 2$ promoter region, the blocks of highly conserved sequence within the very large $3^{\prime}$ untranslated region, ${ }^{67}$ or novel genes (see below). ${ }^{68} 69$

Interestingly, the vast majority of single nucleotide changes in the $M E C P 2$ gene are the result of $\mathrm{C} \rightarrow \mathrm{T}$ transitions at CpG hotspots. ${ }^{41}{ }^{70} 71$ The general restriction of RS to females and the very low recurrence rate ${ }^{72}$ appear to be the result of a large proportion of these mutations arising via spontaneous deamination of 5-methylcytosine to thymine in the heavily methylated male germ cells. ${ }^{73-75}$

A large degree of phenotypic variability is seen in both RS patients and people with MECP2 mutations, ranging from classical RS to normal individuals with protective skewing of $\mathrm{X}$ inactivation. The phenotype associated with MECP2 mutations has broadened even further to include males with severe neonatal encephalopathy, ${ }^{7076}$, males from X linked mental retardation pedigrees, ${ }^{77-81}$ PPM-X syndrome, ${ }^{82}$ Angelman syndrome, ${ }^{83} 84$ and infantile autism. ${ }^{85}$

\section{FUNCTIONAL CONSEQUENCES OF MECP2 MUTATIONS}

MeCP2 was initially thought to function as a global transcriptional repressor, but the specifically neuronal phenotype associated with mutations, and the apparent lack of global gene dysregulation in cell lines from RS patients, ${ }^{86} 87$ and in brains from human RS patients ${ }^{88}$ and RS mouse models, ${ }^{87}$ do not support this suggestion.

Recent studies have begun to identify specific MeCP2 targets. In Xenopus, MeCP2 inhibits the expression of xHairy2a, which itself is a target of the Notch/Delta signalling pathway. ${ }^{89}$ With reduction of MeCP2 activity, xHairy2a expression is increased, and this leads to inhibition of primary neurogenesis. ${ }^{89}$ It will be interesting to study whether MeCP2 plays a role in other Notch regulated aspects of neuronal maturation, including dendritic branching, which is known to be abnormal in the RS brain.

Studies of MeCP2 expression in primate prefrontal cortex demonstrate increases during development, with expression expanding from the deeper cortical layers and subplate in 110 day embryos, to robust expression throughout the prefrontal cortex in adult monkeys. ${ }^{90}$ Moreover, increased MeCP2 expression appears to be associated with neuronal

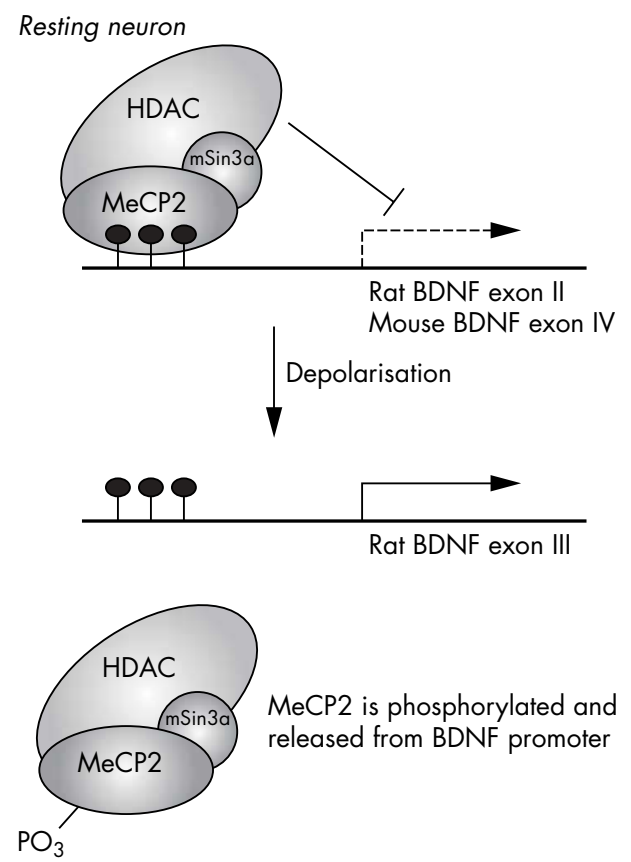

Figure 3 Proposed model for MeCP2 regulated expression of BDNF. In the resting neurone, MeCP2 binds the $B D N F$ promoter, repressing its activity. Following neuronal depolarisation, MeCP2 is phosphorylated, perhaps by CDKL5, leading to its displacement from the BDNF promoter, and thus allowing BDNF activation.

maturation, particularly in the hippocampus, cortex, and cerebellum, the brain regions primarily affected in RS.9192 These combined expression data suggest that MeCP2 has specific functions in neuronal cells of the central nervous system. Indeed, Aber et a $l^{93}$ demonstrated that MeCP2 localises both to the postsynaptic compartments of neuronal cells and to the nucleus, suggesting that MeCP2 links the regulation of transcription to synaptic activity.

Two recent papers have identified one possible MeCP2 target in this pathway in mammals. ${ }^{94} 95$ These authors found that MeCP2 binds specifically to BDNF (brain derived neurotrophic factor) promoter III in rat and promoter IV in mouse, respectively, thereby repressing $B D N F$ transcription in resting neuronal cells. Membrane depolarisation of neuronal cells led to calcium dependent phosphorylation and release of MeCP2 (fig 3), suggesting that MeCP2 may regulate the transcription of activity dependent genes in neuronal cells, ${ }^{94}$ which is important in synapse development and neuronal plasticity.

Deletion of the $\mathrm{C}$ terminus of $M E C P 2$ encompassing the WW domain binding region occurs commonly in RS patients, and is associated with loss of binding to the splicing factors FBPIl and HYPC. ${ }^{36}$ Preliminary evidence from our laboratory suggests that cell lines carrying $C$ terminal deletions may shift towards recruiting smaller protein complexes on binding unmethylated or partially methylated $\mathrm{CpG}$ rich regions (data not shown). As these $\mathrm{C}$ terminal deletions do not disrupt the MBD or the TRD, the pathogenesis in these cases may be due to loss of the WW domain binding region, and hence, loss of the proteins that normally interact with this domain. These findings are yet to be confirmed in brain and neuronal cells, ${ }^{36}$ but if they are, it raises the interesting possibility that MeCP2 is involved in splicing, or that WW binding domains may be found in specific neuronal targets of MeCP2. 


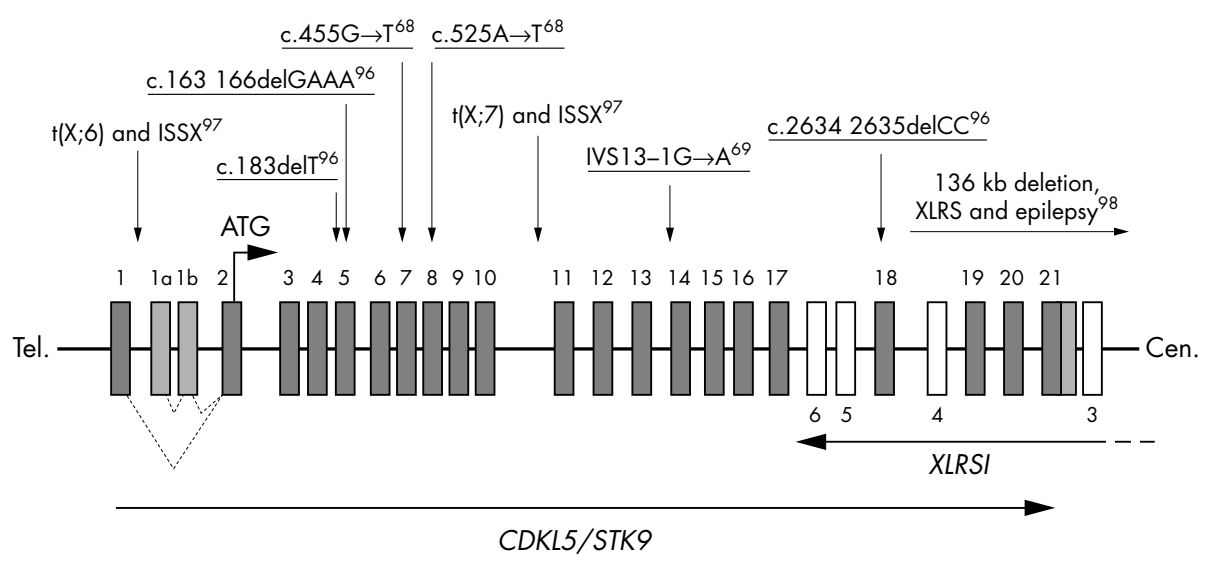

Figure 4 Exon structure of the CDKL5 (STK9) gene and its overlap with the XLRS1 gene. Published mutations involving the CDKL5 gene are indicated with arrows. Mutations found in patients with early seizure variant of RS are underlined. The position of two translocation breakpoints (associated with ISSX) and a deletion involving both $X L R S 1$ and CDKL5 genes is also indicated. All known exons of the CDKL5 gene (solid boxes) and some of the XLRS1 gene (empty boxes) are indicated and numbered.

CDKL5/STK9

\section{CDKL5: A SECOND RS GENE?}

The apparent lack of $M E C P 2$ mutations in a small proportion of clinically well defined RS cases suggests the existence of at least one other RS locus. ${ }^{41} 71$ Three recent reports, ${ }^{686996}$ identified mutations in the gene for cyclin dependent kinase-like 5 (CDKL5; OMIM \#300203; also known as serine threonine kinase 9 (STK9)) in patients who had been diagnosed with atypical RS, supporting the existence of genetic heterogeneity in RS. Somewhat similar to the MECP2 involvement in RS, mutations affecting CDKL5 appear to yield clinical outcomes of varying severity. In addition to two female patients with infantile spasms syndrome, X linked (ISSX) and X;autosome translocations interrupting the CDKL5 gene who were described by Kalscheuer et al, ${ }^{97}$ RS patients with early onset seizures (seven cases), one girl with an autistic disorder and intellectual disability, and a boy with severe, early infantile onset neurological disorder have CDKL5 mutations. ${ }^{68}{ }^{69}{ }^{96}$ Additionally, one male patient with X linked retinoschisis (XLRS) and a large deletion involving at least the last coding exon of the CDKL5 gene had seizures, which are otherwise not associated with XLRS. ${ }^{98}$ In this case it is likely that the seizure phenotype was due to deletion of the CDKL5 gene, but other gene contributions cannot be excluded. In summary, there are currently nine published (fig 4) and at least two unpublished RS cases (personal communication: Dr H Archer, Dr J Evans, Professor A Clarke, Department of Medical Genetics, University of Wales College of Medicine, Cardiff, Wales) with mutations in, or involving the CDKL5 gene. From among these, eight cases have been diagnosed with the atypical, early seizure variant of RS, suggesting that this may be the predominant phenotype caused by CDKL5 mutations. Although still very tentative, some speculations about the CDKL5 mutation genotype/ phenotype correlation can be drawn. While protein truncating mutations at the $\mathrm{N}$ terminal end ${ }^{97}$ cause a severe, early onset phenotype of infantile spasms (phenotype overlapping with that of ISSX as caused by the Aristaless (ARX) gene mutations ${ }^{99}$ ), truncations more towards the $C$ terminal end cause atypical RS in girls, a severe neurological disorder in boys, or autistic disorder with intellectual disability. Tissue specific skewing of $\mathrm{X}$ inactivation, genetic background, and as yet unknown environmental factors may contribute to the phenotypic variability, as revealed in at least one case of discordant monozygous twins. ${ }^{69}$

CDKL5 is a putative serine/threonine kinase of unknown function. ${ }^{100}{ }^{101}$ The connection between CDKL5 and MeCP2, if there is one, and the mechanism by which they produce overlapping phenotypes, will be important questions for future studies to address. CDKL5 mutations appear to be associated with severe, early onset seizures in particular, and thus CDKL5 gene screening should be considered in atypical,
MECP2 negative RS cases. Whether ARX tested negative cases with infantile spasms, or autism spectrum disorder cases with intellectual disability and early onset seizures, should also be considered remains to be investigated.

\section{CONCLUSIONS}

Recent advances in our knowledge of MECP2 splicing, its specific targets, and the phenotypes and expression in mutant mice have greatly contributed to our understanding of the aetiology of RS. Studies in cell lines and mouse models have confirmed the contribution that skewing of $\mathrm{X}$ inactivation can make to phenotypic variability. ${ }^{56-58}$ Identification of Hairy $2 \mathrm{a}^{89}$ and BDNF $^{94}{ }^{95}$ as bona fide targets of MeCP2 has given glimpses of the mechanisms by which MECP2 mutations lead to RS, and have enhanced the understanding of the functions of MeCP2, which no longer appears to be the global transcriptional repressor it was once assumed to be. ${ }^{102}$ Rather, it may function to regulate the dynamic expression of neuronal genes and the formation of new synaptic connections in response to electrical signalling, thereby explaining the specifically neuronal phenotype associated with $M E C P 2$ mutations. Moreover, some of the phenotypic variability observed in RS has been confirmed to result from genetic heterogeneity. Several reports have identified mutations in CDKL5 in specific atypical RS variants associated with early onset seizures. It remains to be determined whether this or other genes are responsible for a significant proportion of atypical RS cases or other neurological phenotypes.

While much has been learnt about RS since its first description over 30 years ago, the pathogenesis of this important and intriguing disorder is still not well understood. To fully explain the RS disease phenotype will require the identification of further gene targets for MeCP2 and CDKL5, particularly those predominantly active in the central nervous system.

Such studies would greatly enhance the understanding of normal brain development and function, and provide opportunities for the development of targeted therapeutic interventions for RS, possibly in the presymptomatic stage or early in the evolution of the disorder.

\section{Authors' affiliations}

L S Weaving, Program in Developmental Biology, the Hospital for Sick Children, Toronto, Canada

C J Ellaway, J Christodoulou, Western Sydney Genetics Program, the Royal Alexandra Hospital for Children, Sydney, and Discipline of Paediatrics and Child Health, University of Sydney, Australia J Gécz, Department of Genetic Medicine, Women's and Children's Hospital, Adelaide, and Department of Paediatrics, The University of Adelaide, Adelaide, Australia

Competing interests: none declared 


\section{REFERENCES}

1 Rett A. Uber ein eigartiges hirnatrophisches Syndrom bei Hyperammoniamie in Kindesalter. Wien Med Wochenschr 1966;116:723-38.

2 Hagberg B, Aicardi J, Dias K, Ramos O. Progressive syndrome of autism, dementia, ataxia and loss of purposeful hand use in girls: Rett's syndrome: Report of 35 cases. Ann Neurol 1983;14:471-9.

3 Hagberg B, Hagberg G. Rett syndrome: epidemiology and geographical variability. Eur Child Adolesc Psych 1997;1:5-7.

4 Leonard $\mathrm{H}$, Bower C, English D. The prevalence and incidence of Rett syndrome in Australia. Eur Child Adolesc Psych 1997:1:8-10.

5 Hagberg B. Rett syndrome: clinical peculiarities and biological mysteries. Acta Paediatr 1995;84:971-6.

6 Amir RE, Van den Veyver IB, Wan M, Tran CQ, Francke U, Zoghbi HY. Rett syndrome is caused by mutations in X-linked MECP2, encoding methyl-CpGbinding protein 2. Nat Genet 1999;23185-8.

7 Trevethan E, Moser H, for the Rett Syndrome Diagnostic Working Group. Diagnostic criteria for Rett syndrome. Ann Neurol 1988;23:425-8.

8 Hagberg B, Hanefeld F, Percy A, Skjeldal O. An update on clinically applicable diagnostic criteria in Rett syndrome. Comments to Rett Syndrome Clinical Criteria Consensus Panel Satellite to European Paediatric Neurology Society Meeting, Baden Baden, Germany, 11 September 2001. Eur J Paediatr Neurol 2002;6:293-7.

9 Kerr AM, Nomura Y, Armstrong D, Anvret M, Belichenko PV, Budden S, Cass $\mathrm{H}$, Christodoulou J, Clarke A, Ellaway C, d'Esposito M, Francke U, Hulten M, Julu P, Leonard H, Naidu S, Schanen C, Webb T, Engerstrom IW, Yamashita Y, Segawa M. Guidelines for reporting clinical features in cases with MECP2 mutations. Brain Dev 2001;23:208-11.

10 Hagberg B, Witt-Engerstrom I. Rett syndrome: a suggested staging system for describing impairment profile with increasing age towards adolescence. Am J Med Genet 1986;24(suppl):47-59.

11 Ellaway CJ, Badawi N, Raffaele L, Christodoulou J, Leonard H. A case of multiple congenital anomalies in association with Rett syndrome confirmed by MECP2 mutation screening. Clin Dysmorph 2001:10:185-8.

12 Leonard H, Weaving L, Eastaugh P, Smith L, Delatycki M, Witt Engerstrom I, Christodoulou J. Trisomy 21 and Rett syndrome: a double burden. J Paediatr Child Health 2004;40:406-9.

13 Hagberg B, Gillberg C. Rett variants - rettoid phenotypes. In: Hagberg B, Anvret M, Wahlstrom J, eds. Rett syndrome-clinical and biological aspects. London: MacKeith Press, 1993:40-60.

14 Schwartzman JS, Bernardino A, Nishimura A, Gomes RR, Zatz M. Rett syndrome in a boy with a $47, X X Y$ karyotype confirmed by a rare mutation in the MECP2 gene. Neuropediatr 2001;32:162-4.

15 Topcu M, Akyerli C, Sayi A, Toruner GA, Kocoglu SR, Cimbis M, Ozcelik T. Somatic mosaicism for a MECP2 mutation associated with classic Rett syndrome in a boy. Eur J Hum Genet 2002;10:77-81.

16 Moog U, Smeets EE, van Roozendaal KE, Schoenmakers S, Herbergs J Schoonbrood-Lenssen AM, Schrander-Stumpel CT. Neurodevelopmental disorders in males related to the gene causing Rett syndrome in females (MECP2). Eur J Paediatr Neurol 2003;7:5-12.

17 Plioplys AV, Kasnicka I. L-carnitine as a treatment for Rett syndrome. South Med J 1993:86:1411-12

18 Ellaway C, Williams K, Leonard H, Higgins G, Wilcken B, Christodoulou J. Rett syndrome: randomized controlled trial of L-carnitine. J Child Neurol 1999;14:162-7.

19 Ellaway CJ, Peat J, Williams K, Leonard H, Christodoulou J. Medium-term open label trial of $\mathrm{L}$-carnitine in Rett syndrome. Brain Dev 2001;23(suppl 1):S85-9.

20 Egger J, Hofacker N, Schiel W, Holthausen H. Magnesium for hyperventilation in Rett's syndrome. Lancet 1992:340:621-2.

21 McArthur AJ, Budden SS. Sleep dysfunction in Rett syndrome: a trial of exogenous melatonin treatment. Dev Med Child Neurol 1998;40:186-92.

22 Budden SS. Management of Rett syndrome: a ten year experience. Neuropediatr 1995;26:75-7.

23 Budden SS. Rett syndrome: habilitation and management reviewed. Eur Child Adol Psych 1997:1:103-7.

24 Glaze DG, Schultz RJ, Frost JD. Rett syndrome: characterization of seizures versus non-seizures. Electroencephal Clin Neurophysiol 1998;106:79-83.

25 Sekul EA, Moak JP, Schultz RJ, Glaze DG, Dunn JK, Percy AK. Electrocardiographic findings in Rett syndrome: an explanation for sudden death? J Pediatr 1994;125:80-82.

26 Ellaway CJ, Sholler G, Leonard H, Christodoulou J. Prolonged QT interval in Rett syndrome. Arch Dis Child 1999;80:470-2.

27 Hanks SB. Motor disabilities in the Rett syndrome and physical therapy strategies. Brain Dev 1990;12:157-61.

28 Adler DA, Quaderi NA, Brown SD, Chapman VM, Moore J, Tate P, Disteche CM. The X-linked methylated DNA binding protein, Mecp2, is subject to X inactivation in the mouse. Mamm Genome 1995;6:491-2.

29 D'Esposito M, Quaderi NA, Ciccodicola A, Bruni P, Esposito T, D'Urso M, Brown SD. Isolation, physical mapping, and northern analysis of the X-linked human gene encoding methyl CpG-binding protein, MECP2. Mamm Genome 1996:7:533-5.

30 Kriaucionis S, Bird A. The major form of MeCP2 has a novel $\mathrm{N}$-terminus generated by alternative splicing. Nucl Acid Res 2004;32:1818-23.

31 Mnatzakanian GN, Lohi H, Munteanu I, Alfred SE, Yamada T, MacLeod PJ, Jones JR, Scherer SW, Schanen NC, Friez MJ, Vincent JB, Minassian BA. A previously unidentified MECP2 open reading frame defines a new protein isoform relevant to Rett syndrome. Nat Genet 2004;36339-41

32 Jones PL, Veenstra GJ, Wade PA, Vermaak D, Kass SU, Landsberger N, Strouboulis J, Wolffe AP. Methylated DNA and MeCP2 recruit histone deacetylase to repress transcription. Nat Genet 1998;19:187-91.
$33 \mathrm{Nan} \mathrm{X}, \mathrm{Ng} \mathrm{HH}$, Johnson CA, Laherty CD, Turner BM, Eisenman RN, Bird A. Transcriptional repression by the methyl-CpG-binding protein MeCP2 involves a histone deacetylase complex. Nature 1998;393:386-9.

34 Kokura K, Kaul SC, Wadhwa R, Nomura T, Khan MM, Shinagawa T, Yasukawa T, Colmenares C, Ishii S. The Ski protein family is required for MeCP2-mediated transcriptional repression. J Biol Chem 2001; 276:34115-21.

35 Yu F, Thiesen J, Stratling WH. Histone deacetylase-independent transcriptional repression by methyl-CpG-binding protein 2. Nucl Acid Res 2000;28:2201-6.

36 Buschdorf JP, Stratling WH. A WW domain binding region in methyl-CpGbinding protein MeCP2: impact on Rett syndrome. J Mol Med 2004:82:135-43.

37 Amir RE, Van den Veyver IB, Schultz R, Malicki DM, Tran CQ, Dahle EJ, Philippi A, Timar L, Percy AK, Motil KJ', Lichtarge O, Smith EO, Glaze DG, Zoghbi HY. Influence of mutation type and $X$ chromosome inactivation on Rett syndrome phenotypes. Ann Neurol 2000;47:670-9.

38 Hoffbuhr K, Devaney JM, LaFleur B, Sirianni N, Scacheri C, Giron J, Schuette J, Innis J, Marino M, Philippart M, Narayanan V, Umansky R, Kronn D, Hoffman EP, Naidu S. MeCP2 mutations in children with and without the phenotype of Rett syndrome. Neurol 2001;56:1486-95.

39 Laccone F, Huppke P, Hanefeld F, Meins M. Mutation spectrum in patients with Rett syndrome in the German population: Evidence of hot spot regions. Human Mut 2001;17:183-90.

40 Huppke $\mathbf{P}$, Held $M$, Hanefeld F, Engel W, Laccone F. Influence of mutation type and location on phenotype in 123 patients with Rett syndrome. Neuropediatr 2002;33:63-8.

41 Weaving LS, Williamson SL, Bennetts B, Davis M, Ellaway CJ, Leonard H, Thong MK, Delatycki M, Thompson EM, Laing N, Christodoulou J. Effects of MECP2 mutation type, location and X-inactivation in modulating Rett syndrome phenotype. Am J Med Genet 2003;118A:103-14.

42 Kammoun F, de Roux N, Boespflug-Tanguy O, Vallee L, Seng R, Tardieu M, Landrieu P. Screening of MECP2 coding sequence in patients with phenotypes of decreasing likelihood for Rett syndrome: a cohort of 171 cases. J Med Genet 2004:41:e85.

43 Schanen C, Houwink EJ, Dorrani N, Lane J, Everett R, Feng A, Cantor RM, Percy A. Phenotypic manifestations of MECP2 mutations in classical and atypical Rett syndrome. Am J Med Genet 2004;126A:129-40.

44 Christodoulou J, Grimm A, Maher T, Bennetts B. RettBASE: The IRSA MECP2 variation database-a new mutation database in evolution. Hum Mut 2003;21:466-72.

45 Leonard H, Colvin L, Christodoulou J, Schiavello T, Williamson S, Davis M, Ravine D, Fyfe S, de Klerk N, Matsuishi T, Kondo I, Clarke A, Hackwell S, Yamashita Y. Patients with the R133C mutation: is their phenotype different from patients with Rett syndrome with other mutations? J Med Genet 2003;40:e52.

46 Colvin L, Leonard H, de Klerk N, Davis M, Weaving L, Williamson S, Christodoulou J. Refining the phenotype of common mutations in Rett syndrome. J Med Genet 2004;41:25-30

47 Camus P, Abbadi N, Perrier MC, Chery M, Gilgenkrantz S. Patterns of X chromosome inactivation in the Rett syndrome. Brain Dev 1990;12:131-5.

48 Camus P, Abbadi N, Perrier MC, Chery M, Gilgenkrantz S. X chromosome inactivation in 30 girls with Rett syndrome: analysis using the probe. Hum Genet 1996;97:247-50.

49 Krepischi AC, Kok F, Otto PG. X chromosome-inactivation patterns in patients with Rett syndrome. Hum Genet 1998;102:319-21.

50 Webb T, Watkiss E, Woods CG. Neither uniparental disomy nor skewed Xinactivation explains Rett syndrome. Clin Genet 1993;44:236-40

51 Anvret M, Wahlstrom J. Rett syndrome: random X chromosome inactivation. Clin Genet 1994;45:274-75.

52 Migeon BR, Dunn MA, Thomas G, Schmeckpeper BJ, Naidu S. Studies of X inactivation and isodisomy in twins provide further evidence that the $X$ chromosome is not involved in Rett syndrome. Am J Hum Genet 1995; $56: 647-63$.

53 Webb T, Watkiss E. A comparative study of X-inactivation in Rett syndrome probands and control subjects. Clin Genet 1996;49:189-15.

54 Hoffbuhr KC, Moses LM, Jerdonek MA, Naidu S, Hoffman EP. Associations between MeCP2 mutations, $X$-chromosome inactivation, and phenotype. Mental Retard Dev Disab Res Rev 2002;8:99-105.

55 Shahbazian MD, Sun Y, Zoghbi HY. Balanced X chromosome inactivation patterns in the Rett syndrome brain. Am J Med Genet 2002;111:164-8.

56 Balmer D, Arredondo J, Samaco RC, LaSalle JM. MECP2 mutations in Rett syndrome adversely affect lymphocyte growth, but do not affect imprinted gene expression in blood or brain. Hum Genet 2002;110:545-52.

57 Young Jl, Zoghbi HY. X-chromosome inactivation patterns are unbalanced and affect the phenotypic outcome in a mouse model of Rett syndrome. Am J Hum Genet 2004;74:51 1-50.

58 Braunschweig D, Simcox T, Samaco RC, LaSalle JM. X-Chromosome inactivation ratios affect wild-type MeCP2 expression within mosaic Rett syndrome and Mecp2-/+ mouse brain. Hum Mol Genet 2004; 13:1275-86

59 Chen RZ, Akbarian S, Tudor M, Jaenisch R. Deficiency of methyl-CpG binding protein-2 in CNS neurons results in a Rett-like phenotype in mice. Nat Genet 2001;27:327-31.

60 Guy J, Hendrich B, Holmes M, Martin JE, Bird A. A mouse Mecp2-null mutation causes neurological symptoms that mimic Rett syndrome. Nat Genet 2001;27:322-6.

61 Gibson J, Williamson S, Arbuckle S, Christodoulou J. X chromosome inactivation patterns of the rain in Rett syndrome: implications for the disease phenotype. Brain Dev (in press). 
62 Erlandson A, Samuelsson L, Hagberg B, Kyllerman M, Vujic M, Wahlstrom J. Multiplex ligation-dependent probe amplification (MLPA) detects large deletions in the MECP2 gene of Swedish Rett syndrome patients. Genet Test 2003;7:329-32.

63 Schollen E, Smeets E, Deflem E, Fryns JP, Matthijs G. Gross rearrangements in the MECP2 gene in three patients with Rett syndrome: implications for routine diagnosis of Rett syndrome. Hum Mut 2003;22:116-20.

64 Ariani F, Mari F, Pescucci C, Longo I, Bruttini M, Meloni I, Hayek G, Rocchi R, Zappella M, Renieri A. Real-time quantitative PCR as a routine method for screening large rearrangements in Rett syndrome: Report of one case of MECP2 deletion and one case of MECP2 duplication. Human Mut 2004;24:172-7

65 Laccone F, Junemann I, Whatley S, Morgan R, Butler R, Huppke P, Ravine D. Large deletions of the MECP2 gene detected by gene dosage analysis in patients with Rett syndrome. Hum Mut 2004;23:234-44. Erratum appears in Hum Mut 2004;23:395.

66 Evans JC, Archer HL, Whatley SD, Kerr A, Clarke A, Butler R. Variation in exon 1 coding region and promoter of MECP2 in Rett syndrome and controls. Eur J Hum Genet 2004; (in press).

67 Coy JF, Sedlacek Z, Bachner D, Delius H, Poustka A. A complex pattern of evolutionary conservation and alternative polyadenylation within the long $3^{\prime}$ untranslated region of the methyl-CpG-binding protein 2 gene (MeCP2) suggests a regulatory role in gene expression. Hum Mol Genet 1999:8:1253-62.

68 Tao J, Van Esch H, Hagedorn-Greiwe M, Hoffmann K, Moser B, Raynaud M Sperner J, Fryns JP, Schwinger E, Gecz J, Ropers HH, Kalschever VM. De novo mutations in the X-linked serine/threonine kinase 9 (STK9) gene are associated with a severe variant of Rett syndrome. Am J Hum Genet 2004;75: Epub.

69 Weaving LS, Christodoulou J, Williamson SL, Friend KL, McKenzie OL, Archer H, Evans J, Clarke A, Pelka GJ, Tam PP, Watson C, Lahooti H, Ellaway CJ, Bennetts B, Leonard H, Gecz J. Mutations of CDKL5 cause a severe neurodevelopmental disorder with infantile spasms and mental retardation. Am J Hum Genet 2004;75:Epub.

70 Wan M, Lee SS, Zhang X, Houwink-Manville I, Song HR, Amir RE, Budden S, Naidu S, Pereira JL, Lo IF, Zoghbi HY, Schanen NC, Francke U. Rett syndrome and beyond: recurrent spontaneous and familial MECP2 mutations at CpG hotspots. Am J Hum Genet 1999:65:1520-9.

71 Miltenberger-Miltenyi G, Laccone F. Mutations and polymorphisms in the human methyl CpG-binding protein MECP2. Hum Mut 2003;22:107-15

72 Kerr AM, Ravine D. Review article: breaking new ground with Rett syndrome J Intellect Disab Res 2003;47:580-7.

73 Thomas GH. High male:female ratio of germ-line mutations: an alternative explanation for postulated gestational lethality in males in X-linked dominant disorders. Am J Hum Genet 1996;58:1364-8.

74 Girard M, Couvert P, Carrie A, Tardieu M, Chelly J, Beldjord C, Bienvenu T. Parental origin of de novo MECP2 mutations in Rett syndrome. Eur J Hum Genet 2001;9:231-6.

75 Trappe R, Laccone F, Cobilanschi J, Meins M, Huppke P, Hanefeld F, Engel W. MECP2 mutations in sporadic cases of Rett syndrome are almost exclusively of paternal origin. Am J Hum Genet 2001;68:1093-101.

76 Amir RE, Zoghbi HY. Rett syndrome: methyl-CpG-binding protein 2 mutations and phenotype-genotype correlations. Am J Med Genet 2000;97:147-52.

77 Meloni I, Bruttini M, Longo I, Mari F, Rizzolio F, D'Adamo P, Denvriendt K, Fryns JP, Toniolo D, Renieri A. A mutation in the Rett syndrome gene, MECP2, causes $X$-linked mental retardation and progressive spasticity in males. Am J Hum Genet 2000;67:982-5.

78 Orrico A, Lam C, Galli L, Dotti MT, Hayek G, Tong SF, Poon PM, Zappella M, Federico A, Sorrentino V. MECP2 mutation in male patients with non-specific X-linked mental retardation. FEBS Lett 2000;481:285-8.

79 Dotti MT, Orrico A, De Stefano N, Battisti C, Sicurelli F, Severi S, Lam CW, Galli L, Sorrentino V, Federico A. A Rett syndrome MECP2 mutation that causes mental retardation in men. Neurol 2002;58:226-30.

80 Kleefstra T, Yntema HG, Oudakker AR, Romein T, Sistermans E, Nillessen W, van Bokhoven $\mathrm{H}$, de Vries BB, Hamel BC. De novo MECP2 frameshift mutation in a boy with moderate mental retardation, obesity and gynaecomastia. Clin Genet 2002;61:359-62.

81 Yntema HG, Kleefstra T, Oudakker AR, Romein T, de Vries BB, Nillesen W Sistermans EA, Brunner HG, Hamel BC, van Bokhoven $\mathrm{H}$. Low frequency of MECP2 mutations in mentally retarded males. Eur J Hum Genet 2002; 10:487-90.
82 Klauck SM, Lindsay S, Beyer KS, Splitt M, Burn J, Poustka A. A mutation hot spot for nonspecific X-linked mental retardation in the MECP2 gene causes the PPM-X syndrome. Am J Hum Genet 2002;70:1034-7.

83 Watson P, Black G, Ramsden S, Barrow M, Super M, Kerr B, Clayton-Smith J. Angelman syndrome phenotype associated with mutations in MECP2, a gene encoding a methyl CpG binding protein. J Med Genet 2001;38:224-8.

84 Kleefstra T, Yntema HG, Nillesen WM, Oudakker AR, Mullaart RA, Geerdink N, van Bokhoven H, de Vries BB, Sistermans EA, Hamel BC. MECP2 analysis in mentally retarded patients: implications for routine DNA diagnostics. Eur J Hum Genet 2004;12:24-8.

85 Beyer KS, Blasi F, Bacchelli E, Klauck SM, Maestrini E, Poustka A International Molecular Genetic Study of Autism Consortium (IMGSAC). Mutation analysis of the coding sequence of the MECP2 gene in infantile autism. Hum Genet 2002;111:305-9.

86 Traynor J, Agarwal P, Lazzeroni L, Francke U. Gene expression patterns vary in clonal cell cultures from Rett syndrome females with eight different MECP2 mutations. BMC Med Genet 2002;3:5.

87 Tudor M, Akbarian S, Chen RZ, Jaenisch R Transcriptional profiling of a mouse model for Rett syndrome reveals subtle transcriptional changes in the brain. Proc Natl Acad Sci USA 2002:99:15536-41.

88 Colantuoni C, Jeon OH, Hyder K, Chenchik A, Khimani AH, Narayanan V, Hoffman EP, Kaufmann WE, Naidu S, Pevsner J. Gene expression profiling in postmortem Rett Syndrome brain: differential gene expression and patient classification. Neurobiol Dis 2001:8:847-65.

89 Stancheva I, Collins AL, Van den Veyver IB, Zoghbi H, Meehan RR. A mutant form of MeCP2 protein associated with human Rett syndrome cannot be displaced from methylated DNA by notch in Xenopus embryos. Mol Cell 2003;12:425-35.

90 Akbarian S, Chen RZ, Gribnau J, Rasmussen TP, Fong H, Jaenisch R, Jones EG. Expression pattern of the Rett syndrome gene MeCP2 in primate prefrontal cortex. Neurobiol Dis 2001;8:784-91.

91 Jung BP, Jugloff DG, Zhang G, Logan R, Brown S, Eubanks JH. The expression of methyl $\mathrm{CpG}$ binding factor MeCP2 correlates with cellular differentiation in the developing rat brain and in cultured cells. J Neurobiol 2003;55:86-96.

92 Shahbazian MD, Antalffy B, Armstrong DL, Zoghbi HY. Insight into Rett syndrome: MeCP2 levels display tissue- and cell-specific differences and correlate with neuronal maturation. Hum Mol Genet 2002;11:115-24.

93 Aber KM, Nori P, MacDonald SM, Bibat G, Jarrar MH, Kaufmann WE. Methyl-CpG-binding protein 2 is localized in the postsynaptic compartment: an immunochemical study of subcellular fractions. Neurosci 2003; 116:77-80.

94 Chen WG, Chang Q, Lin Y, Meissner A, West AE, Griffith EC, Jaenisch R, Greenberg ME. Derepression of BDNF transcription involves calciumdependent phosphorylation of MeCP2. Science 2003;302:885-9.

95 Martinowich K, Hattori D, Wu H, Fouse S, He F, Hu Y, Fan G, Sun YE. DNA methylation-related chromatin remodeling in activity-dependent BDNF gene regulation. Science 2003;302:890-3.

96 Scala E, Ariani F, Mari F, Caselli R, Pescucci C, Longo I, Meloni I, Giachino D, Bruttini $M$, Hayek G, Zapella M, Renieri A. STK9 is mutated in Rett syndrome variant with infantile spasms. J Med Genet (in press).

97 Kalscheuer VM, Tao J, Donnelly A, Hollway G, Schwinger E, Kubart S, Menzel C, Hoeltzenbein M, Tommerup N, Eyre H, Harbord M, Haan E, Sutherland GR, Ropers HH, Gecz J. Disruption of the serine/threonine kinase 9 gene causes severe $X$-linked infantile spasms and mental retardation. Am J Hum Genet 2003:72:1401-11.

98 Huopaniemi L, Tyynismaa H, Rantala A, Rosenberg T, Alitalo T. Characterization of two unusual RS1 gene deletions segregating in Danish retinoschisis families. Human Mut 2000;16:307-14.

99 Stromme P, Mangelsdorf ME, Scheffer IE, Gecz J. Infantile spasms, dystonia, and other X-linked phenotypes caused by mutations in Aristaless related homeobox gene, ARX. Nat Genet 2002;30:441-5.

100 Montini E, Andolfi G, Caruso A, Buchner G, Walpole SM, Mariani M, Consalez G, Trump D, Ballabio A, Franco B. Identification and characterization of a novel serine-threonine kinase gene from the Xp22 region. Genomics 1998:51:427-33.

101 Brunner B, Todt T, Lenzner S, Stout K, Schulz U, Ropers HH, Kalscheuer VM Genomic structure and comparative analysis of nine fugu genes: Conservation of synteny with human chromosome Xp22.2-p22.1. Genome Res 1999;9:437-48.

102 Klose R, Bird A. Molecular biology. MeCP2 repression goes nonglobal. Science 2003;302:793-5. 